\title{
Studies on Incidence and Prevention of Nosocomial Infection of Urinary Tract Endoscopies by Different Antimicrobial Agents
}

F.M. Reda", N.M. Awny and Y.A. Mahmoud, Botany and Microbiology Department, Faculty of Science, Zagazig University, Zagazig, Egypt.

\begin{abstract}
7 HIRTY FIVE bacterial isolates were collected from urine and blood samples of 20 patients, before and after endoscopy examination, in new Surgical Hospitals , Zagazig University Hospital, Zagazig, Egypt. Antibiotic susceptibility profile of purified bacteria revealed four multi-resistant strains identified as Staphylococcus aureus Zag11, Pseudomonas aeruginosa Zag60, Escherichia coli Zag126 and Staphylococcus epidermidis Zag128. The four selected bacteria were subjected to some disinfectants (glutaraldehyde, hydrogen peroxide, P3-oxonia and Orthophthaladehyde) at different concentrations and different exposure times. It was observed that 10 min were enough to inhibit growth of tested pathogenic bacteria in case of $\left(8 \% \mathrm{H}_{2} \mathrm{O}_{2} \& 0.55 \%\right.$ orthophthaladehyde) while completely inhibition was recorded after $15 \mathrm{~min}$ in case of $(2.2 \%$ glutaraldehyde, $70 \%$ ethanol and $0.45 \%$ P3-oxonia). Sterile urinary tract endoscopy was artificially contaminated with mixture $(1: 1: 1: 1: 1: 1)$ of six clinical pathogenic bacterial strains comparing with the four tested bacterial strains. Upon exposing the contaminated endoscope to different chemical disinfectants; $8 \%$ hydrogen peroxide and $0.55 \%$ Orthophthalaldehyde inhibited after 30 min exposure while $2.2 \%$ Glutaraldehyde, $0.45 \%$ P3oxonia and $70 \%$ Ethanol needed $60 \mathrm{~min}$ for complete bacterial inhibition. Upon exposure of artificially contaminated endoscope to different physical agents (U.V, $\gamma$ - rays and dry hot air), Gamma rays showed maximum inhibitory action.
\end{abstract}

Keyword: Nosocomial infection, Urinary tract endoscopies, Antimicrobial agents.

Nosocomial infections called "hospital acquired infections" remain a major worldwide problem, and a lot of people are victims of hospital infections (Edgeworth, 2011). This included infections acquired in the hospital but appearing after discharge and also occupational infections among staff of the facility (Benenson, 1995 and Nguyen, 2004). These infections related to medical care can be devastating and even deadly (Coffin \& Zaoutis, 2008); and also cause significant morbidity and mortality and have a considerable impact on healthcare coats (Ramritu et al., 2008 and Lee et al., 2009). Microorganisms caused hospital infections may be controlled by inhibition or killing by physical or chemical agents as antiseptics, disinfectants, and detergents (Simon et al., 2007). Disinfectants are chemicals agents that destroy the gowing forms of bacteria but do not destroy spore forms of microorganism. Disinfectants are applied on

\#Corresponding author. Tel.: +2-0111-3700513.

E-Mail address: Fifi.reda133@yahoo.com,afmo67@yahoo.com 
lifeless things resembling floor and work benches as phenols, chlorhexidine, hypochlorite and alcohol (Zuhlsdorf et al., 2004). Deconex is a fluid; alkaline, new production of alcohol based disinfectant and is widely used in hospitals and clinics (Penna et al., 2001). Peracetic acid and peroxide hydrogen compounds, and it is a broad spectrum chemical agent that effective against bacteria, fungi, yeasts as well as all known classes of virus. Fort is a chlorhexidine diacetate based disinfectant agent and it may be applied on wet floor, scraper, cotton wipe, wash bucket, or spraying on the inanimate surface (Koburger et al., 2010).

The most common causative bacterial strains for UTIs were coagulase negative Staphylococci and Enterobacter spp. Also, antibiotic multiple resistant Proteus spp., Pseudomonas spp., Klebsiella spp. and Enterococcus spp. can be accounted as the most cause of UTI in renal transplant recipients (Shirazi et al ., 2005). Among the categories of bacteria most known to infect patients are the category MRSA (resistant strain of S. aureus), member of Gram-positive bacteria and Acinetobacter (A. baumannii), which is Gram-negative. While antibiotic drugs to treat diseases caused by Gram-positive MRSA are available, few effective drugs are available for Acinetobacter. Acinetobacter bacteria are evolving and becoming immune to existing antibiotics, so in many cases, polymyxin-type antibacterials need to be used. "In many respects it's far worse than MRSA," said a specialist at Case Western Reserve University (Pollack, 2010).

Short wave ultraviolet radiation (UV 200-280 nm) has been used to disinfect air and surfaces in operating rooms, patient rooms, laboratories and so on, as well as air in ventilation ducts. Despite the well-documented effect of ultraviolet radiation on air quality, thus reducing the occurrence of infections. One advantage of this method is that the UV sources ensure a continuous reduction in the number of airborne microorganisms that are generated all the time (Banrud \& Moan, 1999). The present work was studied the effect of different types of bactericidal agents (physical and chemical agents) on normal and pathogenic isolates which contaminated urinary tract endoscopies.

\section{Materials and Methods}

\section{Bacterial isolation}

Bacteria were isolated from endoscopy before and after operation from urine and blood of 20 patients before the urinary tract endoscopies operation in new Surgical Hospitals, Zagazig University Hospital, and Zagazig, Egypt.

Samples were collected and streaked on different diagnostic and selective agar plates, Nutrient agar, MacConkey agar and Blood agar. Bacterial isolates were streaked for several consecutive times on nutrient agar medium until pure single colonies.

\section{Identification of most pathogenic bacterial isolates}

Identification involved examination the bacterial isolates with naked eye, microscopic examination (Gram's stain) and Physiological biochemical tests according to Bergey's manual (Holt et al., 1994).

Egypt. J. Microbiol. 47 (2012) 
Antibiotic susceptibility test

Antibiotic susceptibility test for the bacterial isolates was carried out by disk diffusion technique according to Baur et al. (1966). The tested antibiotic disks were purchased from Oxoid .

Minimum Inhibitory concentrations (MICs) and Minimum Bactericidal concentrations (MBCs) of tested antibiotics

Two antibiotics were used Ciprofloxacin 1 gm (raw material) from Epico Company and Ofloxacin $250 \mathrm{mg}$ from Al-Ameria Company in Cairo. MICs were determined using broth dilution method of Washington \& Sutter (1980) then MBCs were determined on solid agar media (Moreira et al., 2005).

Selection of the most resistant isolates to $2 \%$ Glutaraldehyde

The bacterial isolates were tested for antimicrobial sensitivity and susceptibility to $2 \%$ glutaraldehyde as the disinfectant.

Effect of different concentrations of different commercial disinfectants on selected isolates

Different disinfectants were tested for its effect on the viability of bacterial isolates as follow: Ethanol (97\%), Orthophthalaldehyde (0.55\%), Hydrogen peroxide (10\%), P3-oxonia (30\%) and Glutaraldehyde (2.2\%).

Physical disinfection of artificially contaminated endoscopy as, Ultra Violet, dry hot air and Gamma rays

Short and long wave length were used to study their effect on urological endoscopy contaminated artificially by mixture of most resistant bacterial suspension (P.aeruginosa Zag60, E.coli Zag126, S.aureus Zag11, S.epidermidis Zag 128), and other endoscopy was contaminated by mixture of (Listeria monocytogenus, Proteus, Klebseilla pneumonia, Salmonella typhi, Bacillus cereus and Shigella dysenteriae) with equal cell concentration $(\mathrm{cfu} / \mathrm{ml})$ for 5 , 10, 20, 30, 40 and $60 \mathrm{~min}$. Also, these endoscopies were disinfected in dry hot oven at different temperature $\left(60,70,80,90 \& 120^{\circ} \mathrm{C}\right)$ for $15 \mathrm{~min}$. The source used for the irradiation process was cobalt - 60 Gamma cells 220, located at the National Center for Radiation Research and Technology, Nasser City, Cairo, Egypt. The three tested organisms S. aureus Zag11 , P. aeruginosa Zag60 and E. coli Zag126 were exposed to gamma radiation at doses of 2, 4, 6, 8 and 10 KGy for S. aureus Zag11 and 2, 4, 6 and $8 \mathrm{kGy}$ for P.aeruginosa Zag60 and E.coli Zag126.

\section{Results and Discussion}

Distribution of collected bacterial isolates from endoscopies before and after operation

Endoscopic procedures carry a risk of microbial infection. Estimating this risk accurately is difficult because ascertaining that a given infection results from 
a contaminated endoscope is not possible. Infection may not be apparent until the patient has been discharged from hospital, and the contaminated endoscope may not be recognized as the source of infection (Weber \& Rutala, 2001). One hundred and thirty five bacterial isolates were collected from endoscopy before and after operation, urine and blood of 20 patients in new Surgical Hospitals, Zagazig University Hospital, Zagazig, Egypt. The collected isolates distributed according to the Gram's stain reaction and morphological characteristics and cell shapes \& arrangements. The results in Table 1 showed that, the 135 isolates were distributed as 70 Gram positive bacterial isolates (51.85\%) and 65 Gram negative bacterial isolates $(48.14 \%)$.

TABLE 1. Distribution of collected bacterial isolates according to their Gram's stain reaction and source of isolation.

\begin{tabular}{|l|c|c|c|c|c|c|}
\hline \multirow{2}{*}{ Source of infection } & \multicolumn{2}{|c|}{$\begin{array}{c}\text { Gram positive } \\
\text { isolates }\end{array}$} & \multicolumn{2}{c|}{$\begin{array}{c}\text { Gram negative } \\
\text { isolates }\end{array}$} & \multicolumn{2}{c|}{ Total } \\
\cline { 2 - 7 } & No. & $\%$ & No. & $\%$ & No. & $\%$ \\
\hline $\begin{array}{l}\text { Endoscopy before } \\
\text { operation }\end{array}$ & 22 & 16.29 & 17 & 12.59 & 39 & 28.89 \\
\hline $\begin{array}{l}\text { Endoscopy after } \\
\text { operation }\end{array}$ & 22 & 16.29 & 23 & 17.03 & 45 & 33.33 \\
\hline Urine of patients & 10 & 7.4 & 12 & 8.8 & 22 & 16.29 \\
\hline Blood of patients & 16 & 11.85 & 13 & 9.6 & 29 & 21.48 \\
\hline Total & 70 & 51.85 & 65 & 48.14 & 135 & 100 \\
\hline
\end{tabular}

Gupta et al. (2007) reported that urinary tract infections are among the most common bacterial infections caused by pathogens with an increasing resistance to several classes of antimicrobials including cotrimoxazole, beta-lactams, amino glycosides, and fluoroquinolones. In this study the antibiotic susceptibility pattern of 35 selected isolates to 10 different antibiotics was investigated by using disc diffusion method. Antibiotics include the following: Cip , OFX , CN , $\mathrm{Cl}$, FOX , CEC, IPM, AZM, C and AX. The results revealed that all isolates were susceptible to Imipenem $(100 \%)$ (the results not shown), so that it represents the most effective antibiotic followed by Ciprofloxacin and Ofloxacin were had $(51.4 \%),(42.9 \%)$ susceptible percentage, respectively. On the other hand, the data showed that $(85.7 \%)$ of bacterial isolates were resistant to Cefoxitin.

Cultural, morphological characters and physiological characteristics of the most resistant strain

The cultural, morphological and physiological characteristics of the selected four isolates which had the higher level of resistance against both different antibiotics and glutraldehyde were studied according to Holt et al. (1994). A highly specific and selective media ; Baired-Parker, and MacConky were used for isolation and enumeration the tested isolates. Table 2 indicated that isolate No. 11 was known as Staphylococcus aureus Zag11. The isolate No. 60 , 126 and 128 were identified and named; Pseudomonas aeruginosa Zag60, Escherichia coli Zag126 and Staphylococcus epidermidis Zag128, respectively. 
TABLE 2. Morphological and biochemical tests for identification of most resistant bacterial isolates.

\begin{tabular}{|c|c|c|c|c|}
\hline \multirow{2}{*}{$\begin{array}{l}\text { Biochemical } \\
\text { tests }\end{array}$} & \multicolumn{4}{|c|}{ Number of isolates } \\
\hline & 11 & 60 & 126 & 128 \\
\hline Gram stain & + ve & $-\mathrm{ve}$ & - ve & + ve \\
\hline Spore forming & - ve & - ve & - ve & - ve \\
\hline Shape & Cocci & Rod & Rod & Cocci \\
\hline Arrangement & $\begin{array}{l}\text { Irregular } \\
\text { Clusters }\end{array}$ & Short rods & Short rods & $\begin{array}{c}\text { Cells in pair } \\
\text { or tetroid }\end{array}$ \\
\hline Color of colonies & $\begin{array}{c}\text { Yellow } \\
\text { raised } \\
\text { circular } \\
\text { colonies 6- } \\
\text { 8m smooth } \\
\text { surface and } \\
\text { entire }\end{array}$ & $\begin{array}{l}\text { White/cramycolonies } \\
\text { on MacConkey } \\
\text { agar medium }, \\
\text { produce blue green } \\
\text { pigment on nutrient } \\
\text { agar }\end{array}$ & $\begin{array}{c}\text { Pink } \\
\text { colonies on } \\
\text { MacConkey } \\
\text { agar } \\
\text { medium }\end{array}$ & $\begin{array}{l}\text { Grayish white } \\
\text { colonies on } \\
\text { nutrient agar } \\
\text { medium } \\
\text { smooth,mucoid } \\
\text { circular entire }\end{array}$ \\
\hline Catalase & + ve & $-\mathrm{ve}$ & $-\mathrm{ve}$ & + ve \\
\hline Indole & $-\mathrm{ve}$ & - ve & + ve & $-\mathrm{ve}$ \\
\hline MR & $-\mathrm{ve}$ & - ve & + ve & - ve \\
\hline $\mathrm{VP}$ & - ve & $-\mathrm{ve}$ & - ve & $-\mathrm{ve}$ \\
\hline Nitrate reduction & $+\mathrm{ve}$ & $+\mathrm{ve}$ & + ve & + ve \\
\hline $\begin{array}{l}\text { Citrate } \\
\text { Utilization }\end{array}$ & - ve & - ve & - ve & - ve \\
\hline Urease & $+\mathrm{ve}$ & $+\mathrm{ve}$ & - ve & $+\mathrm{ve}$ \\
\hline Oxidase & - ve & + ve & - ve & $-\mathrm{ve}$ \\
\hline $\mathrm{H}_{2} \mathrm{~S}$ & - ve & - ve & - ve & - ve \\
\hline Coagulase & $+\mathrm{ve}$ & $-\mathrm{ve}$ & $-\mathrm{ve}$ & $-\mathrm{ve}$ \\
\hline $\begin{array}{l}\text { Gelatin } \\
\text { liguification }\end{array}$ & - ve & + ve & + ve & - ve \\
\hline Motility & Non motile & Motile & Motile & Non motile \\
\hline \multicolumn{5}{|c|}{ Carbohydrate utilization } \\
\hline Glucose & + ve & + ve & + ve & + ve \\
\hline Lactose & $+\mathrm{ve}$ & $+\mathrm{ve}$ & $+\mathrm{ve}$ & $+\mathrm{ve}$ \\
\hline Sucrose & $+\mathrm{ve}$ & - ve & $+\mathrm{ve}$ & + ve \\
\hline Maltose & $+\mathrm{ve}$ & $-\mathrm{ve}$ & $+\mathrm{ve}$ & $+\mathrm{ve}$ \\
\hline D-sorbitol & - ve & - ve & $+\mathrm{ve}$ & $-\mathrm{ve}$ \\
\hline D-Mannitol & $+\mathrm{ve}$ & + ve & + ve & + ve \\
\hline D-Xylose & - ve & $-\mathrm{ve}$ & + ve & $-\mathrm{ve}$ \\
\hline D-Mannose & + ve & - ve & + ve & + ve \\
\hline Identification & S. aureus & P. aeruginosa & E.coli & S.epidermidis \\
\hline
\end{tabular}


Determination of minimum inhibitory concentration and minimum bactericidal concentration of selected antibiotics

The minimum inhibitory concentrations (MICs) and the minimum bactericidal concentrations (MBCs) of Ciprofloxacin (Cip) \& Ofloxacin (OFX) for S.aureusZag11, P.aeruginosaZag6, E.coli Zag126 and S.epidermidis Zag128 were determined. The results in Table (3) showed that all isolates more resistant to OFX than Cip, except S. epidermidis Zag128 strain which indicate the same MIC. The MICs of Cip were $10 \mu \mathrm{g} / \mathrm{ml}$ for P. aeruginosa Zag60 and $S$ .epidermidis Zag128 strains. Nongyao et al. (2005) reported that the three most common pathogens isolated surgical site infection were Escherichia coli, Staphylococcus aureus, and Pseudomonas aeruginosa, which accounted for $15.3 \%, 8.5 \%$, and $6.8 \%$ of infections respectively. Also, the present data showed that the most pathogenic bacterial isolates were S.aureusZag11, E.coli Zag126, P.aeruginosa Zag60, and S.epidermidis Zag128; which were selected for further studies.

TABLE 3. MIC and MBC for selected isolates for Cip and OFX

\begin{tabular}{|l|c|c|c|c|}
\hline \multirow{2}{*}{ Antibiotic } & \multicolumn{2}{|c|}{ Ciprofloxacin (Cip) } & \multicolumn{2}{c|}{ Ofloxacin ( OFX ) } \\
\cline { 2 - 5 } & $\begin{array}{c}\text { MIC } \\
(\mu \mathbf{g} / \mathbf{m l})\end{array}$ & $\begin{array}{c}\text { MBC } \\
(\mu \mathbf{g} / \mathbf{m l})\end{array}$ & $\begin{array}{c}\text { MIC } \\
(\mu \mathbf{g} / \mathbf{m l})\end{array}$ & $\begin{array}{c}\text { MBC } \\
(\mu \mathbf{g} / \mathbf{m l})\end{array}$ \\
\hline S.aureus Zag11 & 20 & 30 & 30 & 30 \\
\hline P.aeruginosa Zag60 & 10 & 40 & 20 & 40 \\
\hline E.coli Zag126 & 5 & 10 & 10 & 30 \\
\hline S.epidermidis Zag128 & 10 & 10 & 10 & 20 \\
\hline
\end{tabular}

Effect of different concentrations of different commercial disinfectants on selected isolates

Microbiocidal activity is affected by age, dilution, and organic stress. Dilution during use is common, and one must ensure that endoscopies or other semi critical items are exposed to an acceptable concentration. Data suggest that $1 \%$ to $1.5 \%$ glutaraldehyde is the minimum effective concentration when used as a high-level disinfectant (Rutala, 1997). In present study, Fig. 1a revealed that the most effective concentration of glutaraldehyde was $2.2 \%$ at $15 \mathrm{~min}$ for inhibition vegetative bacteria and $60 \mathrm{~min}$ to be effective against all bacterial isolates contaminated the urological endoscopy.

Hydrogen peroxide is an oxidizing agent that now is being used to achieve high-level disinfection. Inactivation of microorganisms is dependent on time, temperature, and concentration. $10 \%$ concentration of hydrogen peroxide has been shown to inactivate $10^{6}$ Bacillus species in 60 min, while $3 \%$ concentration killed $10^{6}$ Bacillus species in $150 \mathrm{~min}$ in 6 of 7 trials (Wardle \& Renninger, 1975). The obtained results in Fig. 1b indicated that hydrogen peroxide $10 \%$ has effective against all tested bacteria at 30 min Ortho-phthalaldehyde (OPA), a

Egypt. J. Microbiol. 47 (2012) 
member of the aldehyde family, has recently been introduced as a liquid chemical disinfectant for medical devices (Hession, 2003) .

The high-level disinfectant label claims for OPA solution at $20^{\circ} \mathrm{C}$ vary: 5 min in Europe, Asia and Latin America; $10 \mathrm{~min}$ in Canada; and $12 \mathrm{~min}$ in the United States (Rutala \& Weber, 1999). Fig. 1c demonstrated that the $0.55 \%$ orthophthaldehyde at $30 \mathrm{~min}$ was effective against all bacterial isolates. Also, the most effective concentrations of ethanol were $70 \%$ at 15 min for endoscopy disinfection (Fig. 1d). Ali et al. (2001) showed that alcohols are rapidly bactericidal rather than bacteriostatic against vegetative forms of bacteria; they also are tuberculocidal, fungicidal, and virucidal but do not destroy bacterial spores. Similarly, several new chemical sterilants have been developed recently, including $7.5 \%$ hydrogen peroxide, $0.08 \%$ peracetic acid plus $1.0 \%$ hydrogen peroxide, and $0.55 \%$ orthophthalaldehyde,http://hdl.handle. net/ 10755 / 175734 (2011). Similarly, Ghotaslou \& Bahrami (2012) showed that the chlorhexidine, peracetic acid and an alcohol based compound (Deconex) agents are able to eradicate the bacteria and they can be used lonely. Also, it was proved that the Gram negative bacteria were more resistance to disinfectant relation to Gram positive bacteria.

Peracetic, or peroxyacetic, acid is characterized by rapid action against all microorganisms. Special advantages of peracetic acid are that it lacks harmful decomposition products (i.e., acetic acid, water, oxygen, hydrogen peroxide), enhances removal of organic material, the combination of peracetic acid and hydrogen peroxide inactivated all microorganisms except bacterial spores within 20 min (Tucker et al., 1996). From the present study, the P3-oxonia which consists of Hydrogen peroxide and Peracetic acid was effective in urological endoscopy disinfection at $0.45 \%$ for $60 \mathrm{~min}$ to inhibit all bacterial isolates (Fig. 1 e).

Physical disinfection of artificially contaminated endoscopy as ultraviolet, dry hot air and Gamma rays

The germicidal properties of ultraviolet irradiation are due to the DNA absorption of the UV light, causing cross linking between neighboring pyrimidine nucleoside bases (thymine and cytosine) in the same DNA strand (Miller et al., 1999). Due to the mutated base, formation of the hydrogen bonds to urine bases on the opposite strand is impaired. DNA transcription and replication is thereby blocked, compromising cellular functions and eventually leading to cell death. The amount of cross linking is proportional to the amount of UV exposure. The level of mutations that can be reversed depends on the UV repair system present in the target microorganism. Once the threshold of cross linking has been exceeded, the number of crosslink's is beyond repair, and cell death is occurs (Miller et al., 1999). Table 4 (a,b) showed that the ultraviolet 
(short wave length) has high effect on vegetative cells when it exposed to ultraviolet for $5 \mathrm{~min}$ and lethal effect when it exposed to ultraviolet for $10 \mathrm{~min}$ while ultraviolet has lethal effect on spore forming bacteria when the exposure time is $30 \mathrm{~min}$.

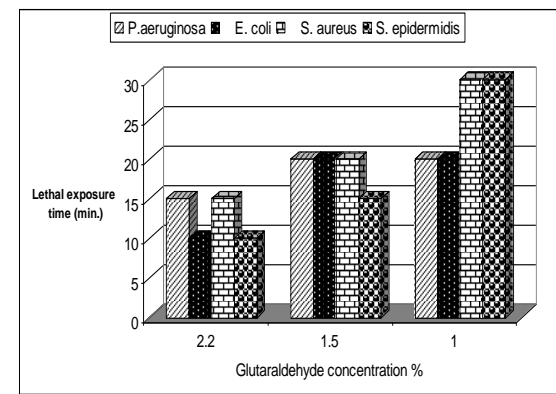

(a)

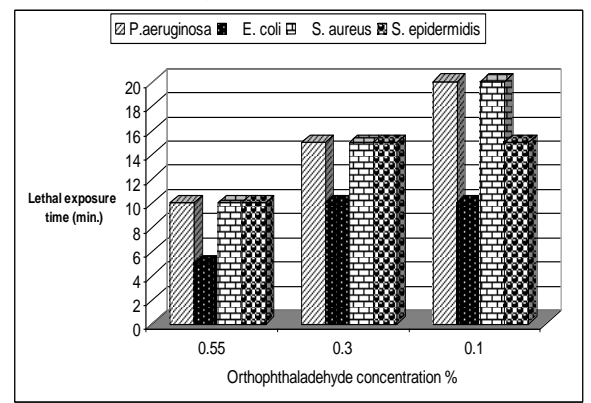

(c)

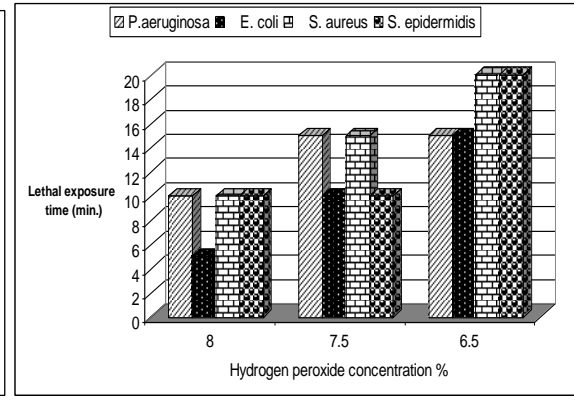

(b)

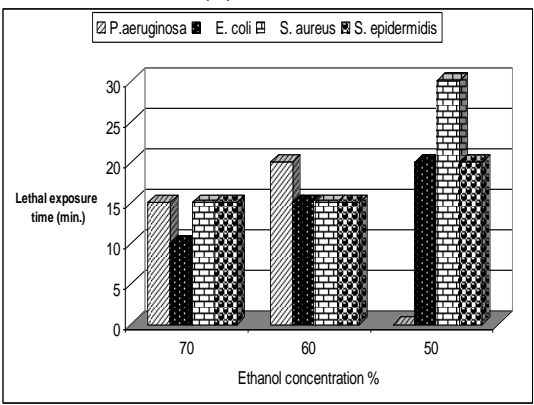

(d)

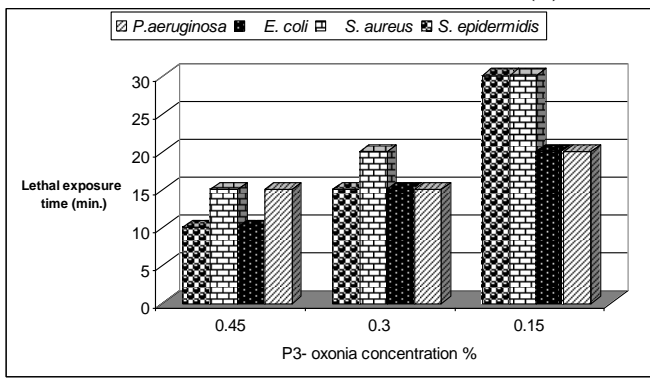

(e)

Fig. 1. Lethal exposure times of different concentrations of (a) glutaraldehyde (b) hydrogen peroxide (c) Orthophthaladehyde (d) ethanol (e) P3-oxonia on $P$. aeruginosa, E. coli, S. aureus and S. epidermidis.

Dry heat coagulates the proteins in all organisms, causes oxidative free radical damage, drying of cells, and can even burn cells to ashes, as seen in incineration (Campbell \& Cripps , 1991). Table (4c) found that the $120^{\circ} \mathrm{C}$ for 15 min was satisfy to disinfect the contaminated endoscopy which used in study.

Egypt. J. Microbiol. 47 (2012) 
TABLE 4. Effect of U.V on endoscopy contaminated with (a) Selected bacterial isolates (S.aureus Zag11, E.coli Zag126, P.aeruginosa Zag60 and S.epidermidis Zag128) (b) Identified pathogenic bacterial isolates (Listeria monocytogenus, Proteus, Klebseilla pneumonia, Salmonella typhi, Bacillus cereus and Shigella (a) dysenteriae) (c) Effect of dry hot air on both contaminated endoscopies:

\begin{tabular}{|c|c|c|c|c|c|c|c|}
\hline $\begin{array}{c}\text { Type of U.V } \\
\text { (at distance 20cm) }\end{array}$ & \multicolumn{7}{|c|}{ Exposure time (min) } \\
\cline { 2 - 9 } & 5 & 10 & 15 & 20 & 30 & 40 & 60 \\
\hline Short wave length & \pm & - & - & - & - & - & - \\
\hline Long wave length & ++ & + & + & + & \pm & \pm & - \\
\hline
\end{tabular}

(b)

\begin{tabular}{|c|c|c|c|c|c|c|c|}
\hline \multirow{2}{*}{$\begin{array}{c}\text { Type of U.V } \\
\text { (at distance } \\
\mathbf{2 0 c m}\end{array}$} & \multicolumn{7}{|c|}{ Exposure time (min) } \\
\cline { 2 - 9 } & 5 & 10 & 15 & 20 & 30 & 40 & 60 \\
\hline Short wave length & ++ & ++ & + & \pm & - & - & - \\
\hline Long wave length & ++ & ++ & ++ & + & + & \pm & - \\
\hline
\end{tabular}

(c)

\begin{tabular}{|c|c|c|c|c|c|}
\hline \multirow{2}{*}{$\begin{array}{l}\text { Growth of bacterial } \\
\text { isolates }\end{array}$} & \multicolumn{5}{|c|}{ Temperature ${ }^{\circ} \mathrm{C}$} \\
\hline & 60 & 70 & 80 & 90 & 120 \\
\hline $\begin{array}{l}\text { Selected bacterial } \\
\text { isolates in this study }\end{array}$ & +++ & ++ & \pm & - & - \\
\hline $\begin{array}{l}\text { identified pathogenic } \\
\text { bacteria }\end{array}$ & +++ & ++ & ++ & \pm & - \\
\hline
\end{tabular}

Figure 2 (a,b and c) studied the effect of gamma radiation (cobalt-60) at different exposure doses (2, 4, 6, 8 and $10 \mathrm{kGy}$ ) for S.aureus Zag11 and (2, 4, 6 and $8 \mathrm{kGy}$ ) for P. aeruginosa Zag60 and E.coli Zag126 and their the dose response curves. The result showed that $3 \mathrm{kGy}$ is enough to destroy the S.aureus Zag11 and $2 \mathrm{kGy}$ to inhibit its toxins production. It was evident that gamma radiation has effect on S.aureus Zagl1 at $4 \mathrm{kGy}$, while has lethal effect at 6 $\mathrm{KGy}$, gamma radiation has high effect on P.aeruginosa Zag60 at $2 \mathrm{kGy}$, while it has lethal effect at $4 \mathrm{kGy}$. On the other hand, gamma radiation has effect on E.coli Zag126 at $2 \mathrm{kGy}$ while has lethal effect at $4 \mathrm{kGy}$. Snyder \& Poland (1995) reported that Gram-positive bacteria are more resistant to gamma radiation than gram-negative bacteria, and also it proved that the doses of 1.6 to $2.5 \mathrm{kGy}$ gamma radiation required for killing $P$. aeruginosa. Meanwhile, radiation dose of $8 \mathrm{kGy}$ resulted in the total elimination of $S$. aureus inoculated in pizza samples (Arzina et al., 2011). 

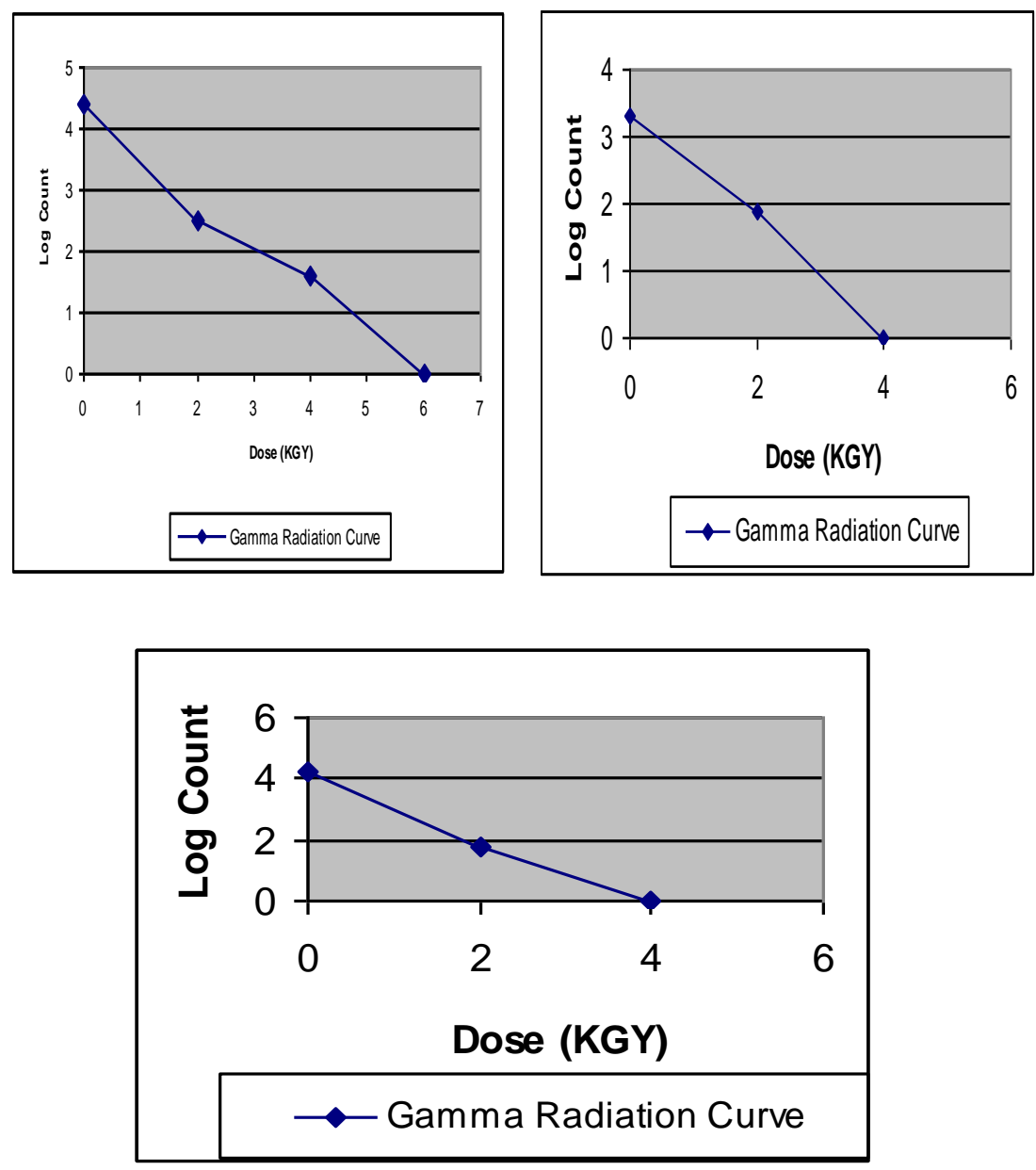

Fig. 2.Bactericidal effect of Gamma rays on the viability of tested isolates (a) S.aureus Zag11 (b) P. aeruginosa Zag60 (c) E.coli Zag126.

\section{Conclusion}

Characteristics of ideal chemical sterilants used as high-level disinfectants which are recommended (Rutala \& Weber, 2004): high efficacy, rapid activity, material compatibility, non toxic, odorless, non staining, resistant to organic material, monitoring capability each use, prolonged reuse life, long shelf life, unrestricted disposal and cost effective. The previous characteristics were achieved in the present study with $8 \%$ hydrogen peroxide for $30 \mathrm{~min}$ and $2.2 \%$ glutaraldehyde for $60 \mathrm{~min} .70 \%$ ethanol and $0.45 \% \mathrm{P} 3$-oxonia for $60 \mathrm{~min}$. 


\section{Reference}

Ali, Y., Dolan, M.J., Fendler, E.J. and Larson, E.L. (2001) Alcohols. In: "Disinfection, Sterilization, and Preservation". Block, S.S. (Ed). Philadelphia: Lippincott Williams \& Wilkins pp. 229-54.

Arzina H., Md. Zahid Hasan, Abdullah- Al-Mahin and Harun- Or-Rashid (2011) Effect of Gamma radiation and low temperature on pathogenic Staphylococcus aureus isolated from Pizza. American Journal of Food Technology,7, 204-213.DOI: 10.3923/ajft.2012.204.213.

Banrud, H. and Moan, J. (1999) Use of short wave ultraviolet radiation for disinfection in operating rooms. Tidsskr. Nor. Laegeforen, 119, 2670-2673.

Baur, A.W., Kirby, W.M.M., Sherris, J.C. and Turck, M. (1966) Antibiotic susceptibility testing by a standardized single disc method. Am. J. Chin. Pathol. 45, 493-496.

Benenson, A.S. (1995) "Control of Communicable Diseases Manual ", $16^{\text {th }}$ ed. Washington, American Public Health Association .

Campbell, M. and Cripps, N. (1991) Environmental control of glutaraldehyde. Hosp Estates J. 45 (2).

Coffin, S.E. and Zaoutis, T.E. (2008) Healthcare- Associated Infections. In: "Principales and Practice of Pediatric Infectious Deases" Long S.S., Pickering L.K., Prober C.G.. $3^{\text {rd }}$ ed. Churchill Livingstone. Chap101.

Edgeworth, J.D. (2011) Has decolonization played a central role in the decline in UK methicillin-resistant Staphylococcus aureus transmission? A focus on evidence from intensive care. J. Antimicrob. Chemother. 66 (2), 41- 47.

Ghotaslou, R. and Bahrami, N. (2012) Antimicrobial activity of chlorhexidine, peracetic acid/ peroxide hydrogen and alcohol based compound on isolated bacteria in Madani Heart Hospital, Tabriz, Azerbaijan, Iran. Advanced Pharmaceutical Bulletin, $2(1), 57-59$.

Gupta, N., Kundra, S., Sharma, A. and Vikas Gautam, V. (2007) Antimicrobial susceptibility of uropathogens in India. J. Infect. Dis. Antimicrob. Agents. 24,13-18.

Hession, S.M. (2003) Endoscopic disinfection by ortho-phthalaldehyde in a clinical setting: An evaluation of reprocessing time and costs compared with glutaraldehyde. Gastroenterol. Nurs. 26,110- 114.

Holt, J.G., Krieg, N.R, Sneath, P.H.A., Staley, J.T. and Williams, S.T. (1994) "Bergey's Manual of Determinative Bacteriology", $9^{\text {th }}$ ed. Baltimore: The Williams \& Wilkins Co. USA.

http://hdl.handle.net/10755/175734 (2011) Disinfection of endoscopes: review of new chemical sterilants used for high-level disinfection. 
Koburger, T., Hubner, N.O., Braun Siebert, M.J. and Kramer, A. (2010) Standardized comparison of antiseptic efficacy PVP-iodine, octenidine dihydrochloride polyhexanide chlorhexidine digluconate. J. Antimicrob. Chemother. 65(8), 17121719.

Lee, C.Y., Chen, P.Y., Huang, F.L. and Lin, C.F. (2009) microbiologic spectrum and susceptibility pattern of clinical isolates from the pediatric intensive care unit in a single medical center - 6 years experience. J. Microbiol. Immunol. infect. 42(2), 160165 .

Miller, R., Jeffrey, W., Mitchell, D. and Elasri, M. (1999) Bacterial responses to ultraviolet light. Am. Soc. Microbiol. 65, 535-541.

Moreira, M.R., Ponce, A.G., del Valle, C.E. and Roura, S.I. (2005) Inhibitory parameters of essential oils to reduce a fooodborne pathogen. LWT, 38, 565-570.

Nguyen, Q.V. (2004) Hospital- acquired infections. J. Hos. Infect. 43 (2), 85-100.

Nongyao, K.R.N., Silom, J. and Virasakdi, C. (2005) Standardized incidence rates of surgical site infection. A multicenter study in Thailand. American J. of Infection Control, 33, 587-594.

Penna, T.C.V., Mazzola P.G. and Martins, A.M.S. (2001) The efficacy of chemical agents in cleaning and disinfection programs. BMC. Infect. Dis. 1,16.

Pollack, A. (2010) "Rising Threat of Infections Unfazed by Antibiotics" New York Times, 27.

Ramritu, P., Halton, K. and Collignon, P. (2008) A systemstic review comparing the relative effectivness of antimicrobial- coated catheters in intensive care units. Am. J. Infect. Control. 36 (2), 104-117.

Rutala, W.A. (1997) Disinfection, sterilization and waste disposal. In: "Prevention and Control of Nosocomial Infections" Wenzel, R.P. (Ed). pp. 539-594. Baltimore. MD: Williams \& Wilkins.

Rutala, W.A. and Weber, D.J. (1999) Disinfection of endoscopes: review of new chemical sterilants used for high-level disinfection. Infect. Control Hosp. Epidemiol 20, 69-76.

Rutala, W.A. and Weber, D.J. (2004) Disinfection and Sterilization In Healthcare Facilities, Hospital Epidemiology, University of North Carolina Health Care System Chapel Hill, NC 27514, Division of Infectious Diseases, University of North Carolina School of Medicine, Chapel Hill, NC 27599-7030.

Shirazi, M.H., Ranjbar, R., Hemati, F. and Sadeghifard, N.(2005) Bacterial infections in renal transplant recipients. Iranian. J. Publ. Health, 34 (3), 62-66.

Simon, A.Y., Ihejirik, K.A., Ogunkoya, A.B., Hassan, A.Z., Adawa, D.A.Y. and Adeyanju, J.B. (2007) Comparison of the antimicrobial efficacy of topical antiseptic creams on canine wounds. Bulgur. J. Veter. Med. 10(4), 273-281. 
Snyder, O.P. and Poland, D.M. (1995) Food Irradiation Today. Hospitality Institute of Technology and Management, St. Paul, Minnesota, USA. In: Food Irradiation, World Health Organization (WHO), Point of Fact, No. 40, Geneva, Switzerland.

Tucker, R.C., Lestini, B.J. and Marchant, R.E. (1996) Surface analysis of clinically used expanded PTFE endoscopic tubing treated by the STERIS PROCESS. ASAIO J. 42, 306- 313 .

Wardle, M.D. and Renninger, G.M. (1975) Bactericidal effect of hydrogen peroxide on spacecraft isolates. Applied Microbiology, 30,710-711.

Washington, J.A. and Sutter, V.I. (1980) Dilution susceptibility test. Agar and macrobroth dilution procedures. P.453-458.In: " Manual of Clinical Microbiology", E.H. Lennette, A. Balows, W. J. Hausler, Jr. and J.P. Truant (Ed.) $3^{\text {rd }}$ ed. American Society for Microbiology, Washingoton, D.C.

Weber, D.J. and Rutala, W.A. (2001) Lessons from outbreaks associated with bronchoscopy. Infect. Control Hosp. Epidemiol. 22, 403-408.

Zuhlsdorf, B., Floss, H. and Matiny, H. (2004) Efficacy of 10 different cleaning processes in a washer-disinfector for flexible endospores. J. Hos. Infect. 56 (4), $305-$ 311.

(Received 6/ 9/2012; accepted $22 / 11 / 2012$ 


\section{دراسات حول حدوث العدوى البكتيرية لمناظير المسالك البولية

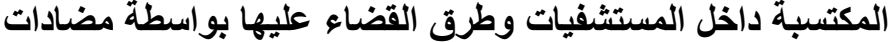 ميكروبية مختلفة}

فيفى محمد رضا ، ناديه محمد عونى و ياسمين أحمد محمود

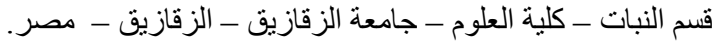

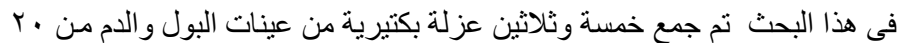

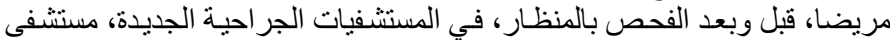

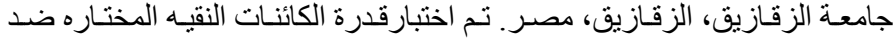
بعض المضادات الحيوية و المعرفه كالاتى S. aureus Zag11 , P. aeruginosa Zag60 , E. coli Zag126 S. epidermidis Zag128,

هذه البكتيريا الأربعة المختارة تم اختتبار هـا لبعض المطهر ات (جلوتار الدهيد

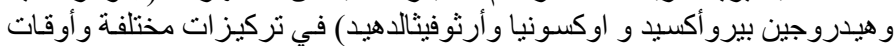

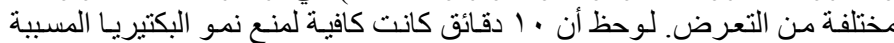

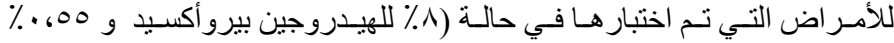

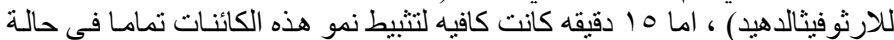

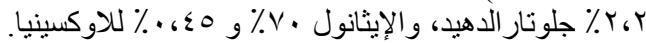

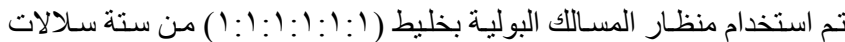

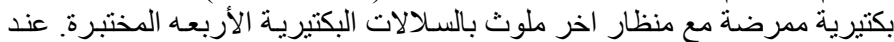

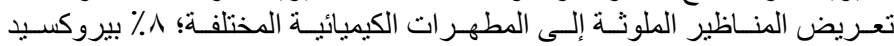

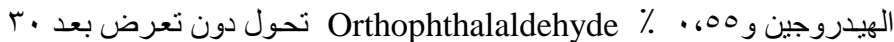

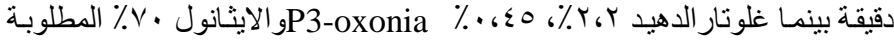

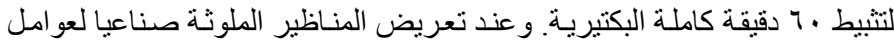

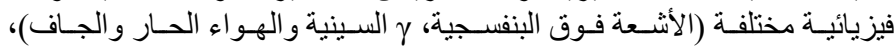
أظهرت أشعة جاما المثبطة عمل كحد أقصى. 